TEME, г. XLI, бр. 3, јул - септембар 2017, стр. 639-652

Прегледни научни рад

DOI: $10.22190 /$ TEME1703639C

Примљено: 13. 1. 2017.

UDK 37.016:[81+82

Ревидирана верзија: 9. 4. 2017.

Одобрено за штампу: 15. 6. 2017.

\title{
ВРСТЕ ТЕКСТОВА У РАЗРЕДНОЈ НАСТАВИ ЈЕЗИКА И КНИЖЕВНОСТИ
}

\author{
Зорица Цветановић ${ }^{1 *}$, Буба Стојановић ${ }^{2}$, Данијела Мишић ${ }^{2}$ \\ ${ }^{1}$ Универзитет у Београду, Учитељски факултет, Броград, Србија \\ ${ }^{2}$ Универзитет у Нишу, Педагошки факултет у Врању, Врање, Србија \\ zorica.cvetanovic@uf.bg.ac.rs
}

\begin{abstract}
Апстракт
Текст, како књижевни тако и некњижевни, вредан је извор информација у настави, али и важан чинилац духовног обликовања и снажан подстицај читалачког задовољства младог бића. Бројна истраживања (PISA, PIRLS, ALL) упозоравају да млади данас имају недовољно развијену читалачку писменост и способност разумевања и самосталног рада на тексту како би открили битне појединости у њему. Текст је лектира која се чита ради уживања у књижевности као уметности или је он помоћ у стицању знања, формирању појмова о одређеним појавама и процесима. Типологија текстова управо се односи на ове две врсте књижевни и некњижевни текстови. Међутим, и једни и други имају више функција у настави језика и књижевности. У раду је дат преглед типологије текстова у научно-стручној литератури и методици језика. Издвојене су типичне поделе и дат је осврт на истраживања у земљи и иностранству. Циљ рада је систематизација врста текстова по својим функцијама у настави језика и књижевности. Подела обухвата букварске, читаначке, лингвометодичке, информативне, научне, инструктивне, предлошке, значењско-корективне и нелинеарне текстове. Све врсте текстова сагледане су са аспекта унапређивања наставе језика и књижевности у млађим разредима основне школе.
\end{abstract}

Кључне речи: текст, врсте текстова, настава језика, настава књижевности, метода рада на тексту.

\section{TYPES OF TEXTS IN CLASS TEACHING OF LANGUAGE AND LITERATURE}

\begin{abstract}
Text, both literary and non-literary, is a valuable source of information in teaching, but also an important factor of spiritual formation and strong stimulus for reading satisfaction of a young human being. Numerous researches (PISA, PIRLS, ALL) warn us that young people today have underdeveloped reading skills, underdeveloped skill to understand and not sufficiently developed skill of independent working on a text in order to discover important details in it. Text is the reading material which is meant to be read
\end{abstract}


because of enjoying literature as an art, or it is some kind of help in gaining knowledge, formation of concepts of certain phenomena and processes. Texts typology refers to these two types - literary and non-literary texts. However, both types have more functions in the teaching of language and literature. This paper offers a review of text typology in scientific and professional literature and language teaching methodology. Typical divisions were marked off and a review of research in the country and abroad was also given. The aim of the paper is systematization of the types of texts according to their functions in the teaching of language and literature. The division includes primer texts, reading book texts, lingual-methodical, informative, scientific, instructional, preschool, meaningfulcorrective and non-linear texts. All types of texts are considered from the aspect of promoting teaching language and literature in lower primary school grades.

Key words: text, types of texts, language teaching, literature teaching, methods of working on a text.

\section{УВОД}

Последице неадекватне комуникације и недостатка прилика да ученици искажу себе и потврде своју личност доказују поражавајући подаци истраживања када је реч о способности ученика у Србији да уче, али и да изражавају и примењују научено. Осим знања страног језика и развијања дигиталних компетенција, млади у Србији, како показују подаци добијени у бројним истраживањима (PISA, PIRLS, ALL), немају довољно развијене читалачке компетенције, односно, способност за активно читање и успешно служење текстом као штампаним медијем. Зато се чини неопходним посебну пажњу посветити методичком раду учитеља и наставника када је реч о читалачкој писмености ученика и избору текстова у настави.

Иако се у студијама које се баве писменошћу у Србији говори о томе како је и на који начин испитивана способност деце за читање (видети више у: Baucal \& Pavlović-Babić, 2010; Pavlović-Babić \& Baucal, 2013; Buđevac \& Baucal, 2014), не постоје детаљна упутства наставницима којим садржајима да унапреде ове области. На пример, научна писменост код деце проверава се читањем одређених текстова и тражењем информација. У циљу побољшања података добијених након PISA тестирања, објављени су, осим приказа резултата, и сами типови задатака који се користе на тестирању (Марковић и сар., 2006; Пејић и Тодоровић, 2007). У овим књигама налазе се задаци са текстовима који учитељима могу помоћи да припреме децу за будућа тестирања. Наставницима је, осим задатака, потребна додатна помоћ приликом одабира садржаја за развијање читалачке писмености ученика, а избор текстова је прва методичка тачка која се налази на том путу.

Појам текст (лат. textus - ткање, плетиво) различито се дефинише. У првим значењима текст представља: „a. наштампане или написане речи, садржина (неке књиге, исправе и сл.), б. оно што се напише или штампа (нпр. чланак у новинама): објављивати текстове у 
штампи" (Речник српскога језика, 2007). У оквиру текстологије текст се дефинише као „графичка или писмена фиксација одређеног дела, односно последњи важећи облик који је аутор дао неком делу, на крају свог стваралачког рада" (Хамовић, 2014). Поједини аутори у теорији текста издвајају и говорни текст (Валгина, 2003, стр. 70). У овом раду донећемо истраживања и типологију писаних текстова у настави језика и књижевности.

Уобичајена подела текстова у литератури је на фикционе (енгл. fiction) и нефикционе (енгл. nonfiction), уз одређење њихове функција у разумевању прочитаног (Meek, 1982; Hiebert, 1999; Tulloch at al. 2012; Duke \& Roberts, 2010; Strachan, 2014). Фикциони, књижевноуметнички текст заснива се на законима размишљања у асоцијативном облику, а нефикциони је у складу са законима логичког размишљања (Валгина, 2003, стр. 70). Типично је да фикциони текстови имају мању читљивост него нефикциони. Области садржаја из науке углавном се ослањају на нефикционе облике текстова (нпр., процедуpe, информациони извештаји) и обезбеђују да читачи усвоје специфична знања - од садржаја до вокабулара (Spencer \& Guillaume, 2006). Управо је начин на који су написани текстови повезан са разумевањем и речником који се разуме при читању. „Књижевни речник се често користи у разговору. Научни речник тежи да буде прецизан и често je технички" (Fang, 2006, p. 510). Дискутовање о сличностима и разликама између читања нефикције и фикције има своју функцију у настави, јер се на тај начин могу истражити интереси и склоности ученика (Palmer \& Stewart, 2005).

\section{ТЕКСТ У У НАСТАВИ ЈЕЗИКА И КЬИЖЕВНОСТИ}

У настави се, поред књижевних, најчешће користе и информативни текстови. На почетку, они имају функцију учења читања и писања, а касније увежбавања читања са разумевањем. За учење читања и писања потребно је користити различите врсте текстова, посебно жанровски разнолике и информативне (Duke, 2010). Ипак, најзначајније је „наћи прави баланс врхунско-квалитетних и комплексних књижевних и информативних текстова у настави" (Strachan, 2014, p. 306).

У новијој литератури, аутори који се баве учењем енглеског језика, односно језика који немају фонетски правопис, издвајају текстове по својој функцији у унапређивању читања. Прво су издвојени декодабилни текстови (енгл. decodable texts), који су намерно написани за вежбање читања и служе за разликовање графичке представе речи од вербалне. Истраживачи препоручују употребу оваквих текстова у учењу језика (Mesmer, 1999; Goodman, 2002), јер су они значајни за разумевање прочитаног на енглеском говорном подручју. За 
почетак учења читања користе се и предвидљиви текстови (енгл. predictable texts) или текстови са језичким обрасцима који се понављају (Moustafa, 1997, p. 21). Текстови на којима се увежбава читање треба да имају фреквентне речи, језичке обрасце који се понављају и да буду разумљиви (Hiebert, 1999, p. 562).

У методици наставе језика, како матерњег тако и страног, текст заузима значајно место јер је средишња методичка категорија. Књижевни текстови чине основу наставе језика. Сваки књижевни текст има индивидуални карактер, како са аспекта продукције (као креативни чин писца) тако и са аспекта читаоца (као доживљај реципијента). У тој индивидуалности потребно је адекватним методичким поступцима обезбедити неопходну компетентност ученика да, као активни читалац, успешно истражује и сазнаје књижевно дело. У настави страног језика текст је такође основ рада зато што се главним задатком наставе сматра оспособљавање ученика за продукцију текстова на страном језику, при чему је веома важно да текстови које користимо буду аутентични (Mišić, 2010, p. 20).

Извори сазнања у настави су књижевни, али и стручни и научно-популарни текстови, односно шира литература (енциклопедије, часописи и др). Избор текстова првенствено зависи од наставних циљева и задатака, али не треба занемарити ни узраст и читалачка интересовања ученика (Стојановић, 2011). Бројне улоге које текст има међусобно су зависне, те се прожимајући, уз ваљано методичко вођење од стране наставника, обезбеђују развијање језичких компетенција, читалачке писмености, али и стицање знања, формирање кључних појмова, критички приступ информацијама (Павловић-Бабић \& Бауцал, 2009; Baucal \& Pavlović-Babić, 2010; Pavlović-Babić \& Baucal, 2013; Visinko, 2014; Žbogar, 2015; Gazdić-Alerić i sar. 2016) како би појединац могао успешно да се снађе у мноштву друштвених улога које савремено доба намеће.

\section{Врсте текстова у настави језика и књижсевности}

Настава почетног читања и писања организује се у првом разреду основне школе, па се текстови који се користе у овом периоду називају према књизи у којој се налазе, по буквару - букварски текстови. Текстови који су предвиђени за читање на часовима Српског језика налазе се углавном у читанци, те су они читаначки текстови. Основна подела текстова у настави језика и књижевности односи се на два периода и предметне области и дата је у Табели 1. 
Табела 1. Врсте текстова према области у настави језика и књижевности

\begin{tabular}{lll}
\hline Предметне области & Врста текста & $\begin{array}{l}\text { Остваривање наставних } \\
\text { циљева }\end{array}$ \\
\hline Почетно читање и & Букварски & $\begin{array}{l}\text { Учење читања и писања } \\
\text { писање }\end{array}$ \\
& Разумевање \\
Кепродукција \\
јњижевност, језик, & Читаначки & Увежбавање читања, \\
& & разумевање и тумачење \\
& & Препознавање, дефинисање, \\
& усвајање и обнављање појмова \\
\hline
\end{tabular}

Ова подела подразумева два периода: први је описмењавање, када ученици уче да читају и пишу, а други се односи на читање, тумачење и учење. Текстови који се користе и у једном и у другом периоду могу бити вишеврсни према својој садржини и намени. Тако се и као букварски и као читаначки текстови могу функционално користити књижевни и некњижевни, фикциони и нефикциони, линеарни и нелинеарни.

Букварски текст је текст на коме се учи и увежбава читање и писање (Милатовић и Ивковић, 2006; Милатовић, 2011; Цветановић, 2010; Cvetanović, 2016). На почетку су то кратки текстови који садрже речи са наученим словима. Пошто је у првим текстовима мало научених слова, речи које имају слова непозната ученицима обично се замењују илустрацијама. Како се број научених слова увећава тако је више сложенијих и разноврснијих текстова (без илустрација). Букварски текст треба да буде прилагођен броју обрађених слова, да буде кратак, јасан, методички функционалан и уметнички вредан.

Читаначки текстови су текстови који се налазе у читанкама, односно у уџбеницима за наставу језика и књижевности (Цветановић, 2008). У настави језика и књижевности, за разлику од других предметних области, у уџбенику (читанци) не доминира уџбенички текст, који је основа за учење у предметима у којима треба изложити програмске садржаје на објективан начин. У млађим разредима основне школе у настави језика ученици најчешће и читају текстове који се налазе у читанкама.

Текстови које читају ученици овог узраста имају своје место и улогу. Сваки текст чита се са неким разлогом - да се сазна, научи, пронађе потребна информација, разуме практично упутство или да се у њему ужива и сазнаје о животу уопште. У наставној теорији и пракси издвајају се различите врсте текстова по својим функцијама у настави језика и књижевности, што је приказано у Табели 2. 
Табела 2. Врсте текстова према функиијама у настави језика и књижевности

\begin{tabular}{ll}
\hline Врста текста & Функције \\
\hline Књижевни & Тумачење \\
Информативни & Обавештавање, добијање информација \\
Лингвометодички & Учење и примена градива из граматике и правописа \\
Научни & Проширивање сазнања, разумевање појава \\
Инструктивни & Упутство \\
Нелинеарни & Проналажење информација или разумевање симболике \\
Текст-предложак & Језички пример \\
Значењско-корективни Разумевање \\
\hline
\end{tabular}

Кьижевни текст је основни садржај и предмет обраде, важан извор језичких примера и подстицај за усмено и писмено изражавање ученика (Маринковић, 1994; Илић, 1998; Смиљковић и Милинковић, 2008; Николић, 2000; Милатовић, 2011; Мркаљ, 2016). Анализа књижевних текстова почиње још у периоду учења читања и писања. Тумачењем ове врсте текста почиње рад на развијању љубави према књизи и читању, али се и естетски и емоционално обликује и духовно богати личност ученика млађег школског узраста (видети више у: Стојановић, 2012, стр. 113-126).

Лингвометодички текст (методички полазни текст) прва је тачка у процесу усвајања граматичких и правописних категорија (Дешић, 1995; Милатовић, 2011). Кључно је да овај текст „мора да буде обогаћен примерима одређене језичке појаве” (Цветановић и Келемен, 2011). Ниједан час граматике или правописа не сме проћи без лингвометодичког текста. Ови текстови могу бити жанровски веома различити. То су углавном „везани (целовити) или невезани текстови” (Дешић, 1995, стр. 205). Везани подразумева краћи текст (басну, краћу причу, новински текст), а невезани текст су посебне реченице које не чине целину.

Информативним текстом добијамо информације и обавештења. То су текстови о појавама и догађајима „писани публицистичким стилом” (Мркаљ, 2016, стр. 177). Њима се извештава. У овим текстовима се на јасан и објективан начин говори о одређеној теми. Иако су прилагођени узрасту ученика, они су без субјективног и имагинарног. Прецизно се говори о предмету излагања (догађају, бићу, предмету, појави), без личног коментара аутора.

Научни текст подразумева научно објашењење одређене природне или друштвене појаве. У ширем смислу, то су „текстови у којима преовладава научни функционални стил: научно-уџбенички текстови, научно-популарни текстови, научно-критички текстови и научно-технички текстови” (Мркаљ, 2016, стр. 177). У млађим разредима, због узраста, чешће се читају научно-популарни и енциклопедијски текстови. Из њих ученици добијају додатна знања и веома су им занимљиви. 
Инструктивни текст представља упутство за одређене радње које треба извршити. У ове текстове спадају инструкције за извођење огледа, рецепти, упутства за употребу апарата. Овакви текстови подразумевају више корака које треба прецизно извршити, укључују процедуру, правила и очекивано понашање од стране читаоца. На занимљив начин оспособљавају децу за пажљиво читање и извршавање инструкција у циљу остваривања практичне, употребне вредности и функционалности нечега.

Нелинеарни текст налази се у табелама, графиконима, сликама. Први нелинеарни текст који ученици пишу и читају у настави је распоред часова. Овај текст нема једнолинијску структуру, карактерише га секвенцијална организација, те зато тражи и другачији приступ при читању. Ако је реченица основна јединица линеарног текста, онда је ,...листа основна организациона јединица нелинеарног текста" (Pavlović-Babić \& Baucal, 2010). Рад на нелинеарном тексту, почев од распореда, преко табела, графикона и мапа ума, било наставников у фази припреме за час или заједнички, ученика и наставника, при тумачењу на часу и благовремено укључивање ученика у читање нелинеарног текста драгоцено је искуство ученику и помоћ при савладавању сложених садржаја осталих предмета.

Текст-предложак служи као основа за писање. Обично се ученицима покаже типски текст који им помаже да и сами пишу. То су писма, честитке, обрасци, потврде, молбе, телеграми и сл. Ту су и други текстови који ученике оспособљавају да се самостално писмено изражавају. Радећи на њима, ученици се уводе у правила службеног комуницирања, које је саставни део живота савременог човека.

Значељско-корективни текстови имају функцију проверавања разумевања прочитаног и пажљивог читања. У њима постоје сувишне речи или реченице које логички не припадају тексту, а ученици треба да их препознају. Користећи ову врсту текстова, подиже се пажња ученика при читању, обезбеђује мотивација за успешно проналажење „уљеза” у реченицама или тексту, развија осећај за склад и хармонију, као и смисао прочитаног, што их додатно мисаоно ангажује.

Продуктиван рад на тексту, као и рад са текстом у настави, у циљу развијања читалачке компетентности ученика, подразумева примену методе рада на тексту или текстовне методе (Вилотијевић, 2000, стр. 290). У литератури се метода рада на тексту среће још као: читање и рад са књигом, рад са текстом, рад са уџбеником и другим штампаним материјалом. Значај самосталног рада ученика са текстом или на тексту је веома велики, а у томе му помаже читање разних врста текстова. Сврха таквог начина рада је оспособљавање ученика да читају, сазнају и самостално уче. По мишљењу когнитивиста, значење текста који се чита конструише се у интеракцији текста и читаоца као активног реципијента прочитаног, који у ову интерак- 
цију уноси „когнитивне и метакогнитивне стратегије рада на тексту, као и претходна знања и искуства укључујући и специфична знања и искуства стечена у ситуацијама читања" (Baucal \& Pavlović-Babić, 2010). Дакле, резултат примене методе рада на тексту је самостално учење које као продукт више нема привидно, већ квалитетно и трајно функционално знање. Многи аутори указују на неминовност примене различитих стратегија рада на тексту (Rončević-Zubković, 2013; Visinko, 2014; Žbogar, 2015) које ће бити у складу са посебним захтевима текста, али и узрасним карактеристикама ученика.

Читање је претпоставка за рад на тексту (без обзира на то о каквом тексту је реч). Рад на тексту подразумева различите активности којима се „води” учениково мишљење. Он се упућује, усмерава, наводи, осамостаљује у уочавању и запажању, те се на тај начин постиже већа позорност при самом читању, а истовремено стварају услови за касније изражавање сазнатог и наученог (писмено, усмено, ликовно, музичко, манипулативно).

\section{ТЕКСТ У НАСТАВИ СТРАНОГ ЈЕЗИКА}

Осим приступа тексту као полазној категорији у српском као матерњем језику, од значаја је и специфичан приступ тексту у настави енглеског као страног језика. Књига као уџбеник и књижевни текстови енглеског језика као почетни и најзначајнији писани (знаковни) медији користе се за остваривање задатака и циљева предвиђених програмом и специфичности учења страног језика. Настава учења страног језика омогућава младом реципијенту да, радећи на добро одабраном тексту, уђе у суштину језика, осети његову мелодију, схвати фонетски систем, обогати речник и реченицу (видети више у: Мишић, 2012, стр. 127). Најважније од свега је сазнање да ће ученик тим својствима језика моћи да открије значење књижевног текста. Наставник треба да поседује велику мудрост како би реципијенте енглеског језика мотивисао да кроз дијалог и интеракцију, путем више мисаоних операција кроз које пролази сазнајни процес у раду на тексту, осветлили значење речи и реченица при његовом читању или слушању. Таквим стваралачким односом према језику као систему који упознаје путем писаног текста, уз помоћ маште и мисли, ученик ће моћи да визуелно-текстовне садржаје претвори, осмисли у текст проткан личним доживљајем. Читањем таквих текстова, насталим на енглеском језику, они ће спољашњи (виђени) свет претварати у сопствени (унутрашњи). Тако постају ствараоци слободних усмених и писмених састава у оквиру наставног процеса и литерарних активности у оквиру наставе страног језика. Сваки текст подразумева другачији приступ, сваки сегмент часа енглеског језика другачији је од претходног, наредна наставна ситуација подстиче но- 
ву, тако да ни у једном моменту на часу обраде текста, обнављања и усавршавања сазнатог нема прописаних модела, сем претпоставки или препорука за иновативни приступ језику.

Језик се огледа у књижевном тексту тако да ученици, читајући текст и уочавајући његов смисао, успостављају комуникацију са јунацима. У самом тексту путем мелодије речи и значења уочавају систем који им омогућава учење законитости, развија способност комуницирања језиком који се не претаче у матерњи, али се њиме успоставља мост од страног ка матерњем и обрнуто. Тиме се потврђује да се говорним ситуацијама проистеклим из полазног текста постиже не само билингвизам већ и димензија мултикултуралности. За разлику од традиционалног билингвизма, у коме реципијент разуме језик, а не говори њиме, билингвизам данас помаже да језичка знања ученика стечена радом на тексту допринесу квалитетној комуникацији у говору и писању. Савремена настава треба да води и отклањању лингвистичке интерференције која се јавља у учењу језика у случају када корисници не могу да раздвоје коришћење двају језика, а манифестује се најчешће кроз језичке мешавине, употребу страног акцента, конгруенције и сл. У свему томе, осим живог говора наставника, могу помоћи и текстови које ученици слушају са медија, али и читање и разговор о књижевним делима енглеских аутора која су у програму. Још од предшколског узраста деца почињу схватати да се језици мешају, утичу једни на друге, те да је велико богатство појединца у знању страног језика и оспособљености да чита и пише на њему.

Истраживачким и стваралачким начином рада на тексту у учењу страног језика код ученика се ствара здрава основа за дограђивање сазнања и богаћење духовне моћи која ће им у различитим ситуацијама бити од користи. Актуелно у настави страног језика и савремено у приступу личности ученика отвориће различите могућности читања, поновљеног читања и доживљавања симболике језика у тексту, али и уочавања језичке синонимије и хомонимије. У основној школи путем индивидуализације и диференцијације у процесу учења страног језика, као и квалитетним избором књижевних текстова и прилагођавањем захтевима програма и узрасту ученика, могу се постићи добри резултати.

\section{ЗАКЉУЧАК}

Велики део свога знања и умења појединац стиче помоћу писане речи. Значај самосталног рада ученика са текстом или на тексту је веома велики, а у томе му помаже читање разних врста текстова. Сврха таквог начина рада је оспособљавање деце да самостално читају, сазнају и уче. По мишљењу когнитивиста, значење текста који се чита конструише се у интеракцији текста и читаоца, под условом 
да читалац постаје активни реципијент прочитаног који у ову интеракцију уноси когнитивне и метакогнитивне стратегије рада на тексту, као и претходна знања и искуства, укључујући и специфична знања и искуства стечена у ситуацијама читања.

Текстуални извори знања и у савременој школи главни су извори информација, а рад са текстом незаобилазни део процеса учења, којем се у нашим школама не посвећује довољна пажња. Учење из текста не значи дати ученику да готове информације научи напамет, већ значи оспособити га да мотивисано чита, истражује, промишља, закључује и даље примењује научено у новим и непознатим ситуацијама. На тај начин се подстичу различите когнитивне способности, а учење прелази репродуктивни ниво, како је најчешће у школи данас, и добија одлику продуктивности и функционалности.

У млађим разредима основне школе ученици читају разноврсне текстове. У настави књижевности књижевни текст је основни садржај, а у настави граматике и правописа то је лингвометодички текст. Информације и обавештења добијамо из информативног текста. На овом узрасту веома често се читају и научно-популарни и енциклопедијски текстови. Осим ових, ученици читају и инструктивне, нелинеарне, значењско-корективне текстове. У правила службеног комуницирања уводе се уз помоћ текст-предлошка, који је основа за писање. Све ове врсте текстова имају велику вредност у настави матерњег и страног језика.

Сваки текст чита се са неким разлогом - да се сазна, научи, пронађе потребна информација или практично упутство, да се у њему ужива и сазнаје о животу уопште. Улоге текста бројне су и међусобно зависне, те прожимајући се уз ваљано методичко вођење од стране наставника обезбеђују развијање језичких компетенција, читалачке писмености, али и стицање знања, формирање појмова и критички приступ сазнатом. Феномен читања и рада на тексту било које врсте веома је важан за развој личности и његово стручно оспособљавање како би се појединац снашао у мору информација и мноштву улога савременог друштва. Будућа истраживања стога би требало усмерити у правцу ефикасности методичких поступака и примене различитих стратегија рада на тексту са циљем унапређивања читалачких компетенција ученика.

\section{ЛИТЕРАТУРА}

Baucal, A., Pavlović-Babić, D. (2010). Nauči me da mislim, nauči me da učim, PISA 2009 u Srbiji: prvi rezultati [Teach me to think, teach me to learn, PISA 2009 in Serbia: the first results]. Beograd: Institut za psihologiju Filozofskog fakulteta u Beogradu, Centar za primenjenu psihologiju.

Буђевац, Н., Бауцал, А. (2014). Развој читалачке писмености током прва четири разреда основне школе [Development of reading literacy in lower primary school grades]. Иноваиије у настави, 27 (2), 22-29. 
Cvetanović, Z., Janićijević, V. (2016). Literary texts in the early teaching of reading and writing. In: I. Radovanović, Z. Zaclona (Ed.): Modern trends in teaching and education (139-151). Belgrade, Nowy Sącz: University of Belgrade, Państwowa Wyższa Szkoła Zawodowa.

Цветановић, 3., Келемен, Љ. (2011). Методичко моделовање часа наставе граматике и правописа [Methodological modelling of the grammar and orthography]. Иноваиије у настави, 24 (1), 17-26.

Цветановић, 3., Јанићијевић, В., Мићић, В. (2010). Методички аспекти савременог буквара [Methodical aspects of a contemporary primer]. У Б. Јордановић (Прир.). Буквари и букварска настава код Срба [Primers and primers teaching in Serbs] (287-305). Београд: Педагошки музеј.

Цветановић, 3. (2008). Методичка функција читаначког текста [Methodical function of text from reader]. У Т. Росић (Прир.), Кюижевност за деиу у науци и настави [Literature for children in science and teaching] (456-466), Јагодина: Педагошки факултет.

Дешић, М. (1995). Лингвометодички текст [Linguistic-methodical text]. У В. Цветановић, В. Милатовић и А. Јовановић (Прир.), Методика наставе српског језика и кьижевности [Methodics of teaching Serbian language and literature] (стр. 329-332). Београд: Учитељски факултет.

Duke, N. K., Roberts, K. L. (2010). Genre specific nature of reading comprehension and the case of informational text. In: D. Wyse, R. Andrews, J. Hoffman (Ed.): The International handbook of English, language and literacy teaching (74-86). London: Routledge.

Gazdić-Alerić, T., Alerić, M., Budinski V., Kolar Billege M. (2016). Čitanje kao višefunkcionalna kompetencija [Reading as multifunctional competence], u Mednarodni posvet Partnerstvo Pedagoške fakultete Univerze v Ljubljani in vzgojno-izobraževalnih inštitucij 2016 [International conference Partnership of Pedagogical facultuies of The University in Ljubljana and educational institutions 2016], ur. Tatjana Devjak in Igor Saksida. Ljubljana. 9-20.

Goodman, Y., Goodman, K., Martens, P. (2002). Text matters: Readers who learn with decodable texts. In: Schallert, D. L., Fairbanks, C. M., Worthy, J., Maloch, B., Hoffman, J. V. (Ed.): Fifty-first yearbook of the National Reading Conference (186-203). Oak Creek, WI: National Reading Conference.

Fang, Z. (2006). The language demands of science reading in middle school. International Journal of Science Education, 28 (5), 491-520.

Хамовић, В. (2014). Текст [Text]. У Пијановић П. (Прир.). Лексикон образовних термина [Lexicon of educational terms] (стр. 797-798). Београд: Учитељски факултет.

Hiebert, E. H. (1999). Text matters in learning to read (Distingvished Educators Series). The Reading Teacher, 52, 552-565.

Илић, П. (1998). Српски језик и књижевност у наставној теорији и пракси [Serbian language and literature in the teaching theory and practice]. Нови Сад: Змај.

Маринковић, С. (1994). Методика креативне наставе српског језика и кьижевности [Methodics of creative teaching Serbian language and literature]. Београд: Креативни центар.

Марковић, С., Кировски, Н., Мркаљ, З., Рикало М., Вуковић Љ., Мадарас, М., Продановић, Р., Перовановић М. (2006). Збирка модела задатака по нивоима постигнућа, српски језик и математика за трећи разред основне школе [A collection of task models according to the levels of achievement, Serbian language and mathematics for the third primary school grade]. Београд: Завод за вредновање квалитета образовања и васпитања. Преузето са http://www.ceo.edu.rs. 
Meek, M. (1982). Learning to read. London: The Bodley Head.

Mesmer, H. A. E. (1999). Scaffolding a crucial transition using text with some decidability. The Reading Teacher, 53 (2), 130-142.

Милатовић, В. (2011). Методика наставе српског језика и књижевности у разредној настави [Methodics of teaching Serbian language and literature in class teaching]. Београд: Учитељски факултет.

Милатовић, В., Ивковић А. (2006). Методички приручник уз буквар и наставне листове [Methodical handbook with primer and teaching worksheets]. Београд: Завод за уџбенике.

Мишић, Д. (2012). Ученик између традиционалног и савременог у учењу енглеског језика и улога наставника и школског библиотекара [Student between traditional and modern in learning English language and the role of teachers and the school librarian]. Иновачије у настави, 25 (1), 127-133.

Mišić, D. (2010). Razvoj engleskog govornog i pisanog izraza i funkcija školskih biblioteka [English oral and written expression development and the function of school libraries]. Vranje: Učiteljski fakultet u Vranju.

Moustafa, M. (1997). Bravo to Allington. Reading Today, 15 (4), 18-28.

Мркаљ, 3. (2016). Од буквара до читанки (методичка истраживања) [From primers to readers (Methodical research)]. Београд: Учитељски факултет.

Николић, М. (2000). Методика наставе српског језика и књижевности [Methodics of teaching Serbian language and literature]. Београд: Завод за уџбенике.

Pavlović-Babić, D., Baucal, A. (2013). Podrži me, inspiriši me, PISA 2012 u Srbiji: prvi rezultati [Support me, inspire me, PISA 2012 in Serbia: the first results]. Beograd: Institut za psihologiju Filozofskog fakulteta u Beogradu, Centar za primenjenu psihologiju.

Pavlović-Babić, D., Baucal, A. (2010). Čitalačka pismenost kao mera kvaliteta obrazovanja: procena na osnovu PISA 2009 podataka [Reading literacy as a measure of the quality of education: estimation based on PISA 2009 data]. Psihološka istraživanja, 13 (2), 241-260.

Pavlović-Babić, D., Baucal, A. (2009). Разумевање прочитаног PISA 2003 и PISA 2006 [Reading comprehension PISA 2003 and PISA 2006]. Београд: Министарство просвете, Завод за вредновање квалитета образовања и васпитања, Институт за примењену психологију Филозофског факултета у Београду.

Palmer R. G., Stewart R. A. (2005). Models for using nonfiction in the primary grades, International Reading Association. 58 (5), 426-434.

Пејић, А., Тодоровић, О. (2007). Национално тестирање ученика четвртог разреда приручник за наставнике [National testing of students of the fourth primary grade, handbook for teachers]. Београд: Завод за вредновање квалитета образовања и васпитања. Преузето ca http://www.ceo.edu.rs.

Речник српскога језика [Dictionary of Serbian language] (2007). Нови Сад: Матица српска.

Rončević-Zubković, B.: Samoregulacija čitanja [Self-regulation of reading], u Čitanje za školu $i$ život [Reading for school and life], Zbornik radova, ur. Miroslav Mićanović, 2013, Zagreb: Agencija za odgoj i obrazovanje, 33-41. Preuzeto sa http://www.azoo.hr/images/izdanja/citanje/Citanje.pdf.

Spencer, B., Guillaume, A. M., (2006). Integrating curriculum through the learning cycle: Content-based reading and vocabulary instruction. The Reading Teacher, 60 (3), 206-219. 
Смиљковић, С., Милинковић, М. (2008). Методика наставе српског језика и кьижевности [Methodics of teaching Serbian language and literature]. Врање: Учитељски факултет.

Strachan S. L. (2014). Expanding the range of text types used in the primary grades, The Reading Teacher, 68 (4), 303-311.

Стојановић, Б. (2012). Развој естетских и емоционалних компетенција ученика кроз уметност речи [Development of aesthetical and emotional competencies of students through the art of words]. Педагогија, 67 (1), 113-126.

Стојановић, Б. (2011). Избор књижевних текстова у наставном програму и читанкама и интересовања ученика млађих разреда основне школе [А selection of literary texts in the curriculum and readers and interests of lower primary grades students]. У С. Маринковић, М. Кундачина (Прир). Настава и учење - стање и проблеми [Teaching and learning - Status and Problems] (473-486). Ужице: Учитељски факултет.

Tulloch, K., Cullen, J., Jones, E., Saunders, L., Turner, G. (2012). Primary English across the Curriculum. Los Angeles, London, New Delhi, Singapore, Washington DC: SAGE, Learning Matters.

Валгина, Н. С. (2003). Теория текста [Text theory]. Москва: Логос.

Вилотијевић, М. (2000). Дидактика, организација наставе [Didactics, organization of teaching]. Београд: Учитељски факултет и Завод за уџбенике и наставна средства.

Visinko, K. (2014): Čitanje - poučavanje i učenje [Reading - teaching and learning]. Zagreb: Školska knjiga.

Žbogar, A. (2015). Čitalačka sposobnost i književna kompetencija u nastavi književnosti i jezika u Sloveniji [Reading skills and literary competence in teaching literature and language in Slovenia]. Croatian Journal of Education: Hrvatski časopis za odgoj i obrazovanje, 17(4). doi:10.15516/cje.v17i4.1271, 1234-1247.

\title{
TYPES OF TEXTS IN CLASS TEACHING OF LANGUAGE AND LITERATURE
}

\author{
Zorica Cvetanović ${ }^{1}$, Buba Stojanović ${ }^{2}$, Danijela Mišić ${ }^{2}$ \\ ${ }^{1}$ University of Belgrade, Teacher Education Faculty, Belgrade, Serbia \\ ${ }^{2}$ University of Niš, Faculty of Pedagogy in Vranje, Vranje, Serbia
}

\section{Summary}

Texts have their own function in teaching. Their role is to find out and learn as well as to stimulate reading satisfaction among students. Numerous researches warn us that young people nowadays lack developed reading skills. To develop them, the focus should be on the reading material which is meant to be read to enjoy literature as an art or as a kind of help to gain knowledge, form concepts of certain phenomena and processes.

The most widely-used texts in literature are described as fiction and non-fiction. Fiction is the base of literature teaching while science is mostly based on non-fiction. Informative texts are very often used to practise reading comprehension. The authors that deal with teaching English put a focus on decodable texts that contain frequent words and have the purpose of distinguishing a graphic form of the word from the 
verbal one. For the very beginning of learning to read, predictable texts are used or the texts with language forms that are repeated.

Language teaching starts by learning how to read and write and that is when primer texts are used. In the beginning, they are short but the more learnt letters there are, the more complex and various they get. Reading book texts are found in readers, actually in textbooks designed for teaching language and literature. The texts used in primers and reading books can be literary and non-literary, fictional and non-fictional.

In teaching theory and practice there are two different types of texts with different functions that they have in language and literature teaching. In literature teaching a literary text is the basic content and the main subject worked on. Learning grammar and spelling starts with a lingual-methodical text enriched with examples of a language phenomenon that is being studied. We get information and notices from informative texts. Scientifically popular texts and those from encyclopedias are often read in lower grades. Instructions are written in a manual (e.g. how to use a device). Non-linear texts are found in tables, charts and pictures and they stimulate divergent opinions. There are a lot of extra words or sentences in meaningful-corrective texts so their function is to check if reading was careful enough. A text-template is the base for writing (a greeting card, a form) that introduces students to the rules of formal communication.

Texts read by pupils in lower grades of primary school have their place and role. It is of great importance to find the balance and offer them various texts. Every text is read for a certain reason-to find out, learn, find necessary information or practical instructions or to enjoy it and learn about life in general. 